Revista Iberoamericana, Vol. LXXIII, Núm. 220, Julio-Septiembre 2007, 515-539

\title{
MITO Y MÓNADA: LA COSMOVISIÓN ANDINA COMO BASE DE LA ESTÉTICA VANGUARDISTA DE GAMALIEL CHURATA
}

POR

\author{
Marco Thomas Bosshard
}

Universität Kassel

Ignorada o despreciada por la mayor parte de la crítica literaria peruana durante los decenios pasados, la obra literaria de Arturo Peralta Miranda (1897-1969) -más conocido bajo el pseudónimo "Gamaliel Churata"- ha sido revalorizada en años recientes por toda una serie de estudios científicos (véanse Aramayo; Unruh; Badini; Gonzalez Vigil; Huamán; Gonzáles Fernández y Ríos Moreno; Pantigoso), a pesar de que solamente parte de ellos han sido publicados. Del mismo modo, también la revista literaria dirigida por Churata, el Boletín Titikaka, ha sido objeto de trabajos críticos (véanse Wise; López Lenci; Vich; Zevallos Aguilar), dado que proporcionó un espacio abierto tanto para los miembros del grupo vanguardista puneño Orkopata, liderado por Churata, como para otros poetas y ensayistas peruanos y latinoamericanos, mediando entre un nivel regional y nacional, e incluso internacional, al haber establecido canjes con revistas importantes de Buenos Aires, México, París y Berlín, por ejemplo. En la obra más importante de Churata, en el marco del libro casi críptico titulado El pez de oro -escrito desde los años veinte del siglo xx, pero recién publicado en el exilio boliviano en 1957-, el autor teoriza la poética empleada por los integrantes del Grupo Orkopata. El libro consiste en un conglomerado textual híbrido, en el que se alternan prosa y poesía vanguardista, ensayos de contenido filosófico y elementos dramáticos, todo escrito en un castellano barroco y altamente indigenizado, un lenguaje que contiene una variedad de conceptos y neologismos en quechua y aymara. Ocupa pues -justamente por estas características- una posición singular y al mismo tiempo ejemplar dentro de la producción literaria de los países andinos del siglo xx. No es ninguna exageración afirmar que El pez de oro es una de las obras literarias claves de la modernidad peruana y andina. Una modernidad que se forjó o se está tal vez forjando todavía, a partir, por un lado, de un proyecto de modernización tecnológica y política y, por el otro, del intento a menudo contradictorio a este propósito, consistente en integrar la población indígena, con todas sus creencias y estructuras sociales consideradas premodernas, al Estado nacional moderno en formación. A El pez de oro le corresponde tal estatus, dentro de las letras andinas, porque trata de sintetizar, de manera radical, las poéticas vanguardistas de la época con el discurso indigenista, produciendo una estética muchas veces incomprendida, que busca basarse explícitamente sobre las premisas cosmológicas de las culturas indígenas andinas en transformación. 
Dado que el marco restringido de este artículo no me permite resumir todas las partes de mi interpretación de El pez de oro, que desarrollo más ampliamente en otro lugar -en una monografía que, hasta ahora, sólo está accesible en lengua alemana--, ${ }^{1}$ me limitaré a esbozar cómo se efectúa esta construcción de una estética andina en conexión con el vanguardismo literario en la escritura de Gamaliel Churata, dejando de lado otros aspectos como la historia de la recepción y la vinculación del texto con el discurso y la narrativa indigenista o la comparación más detallada del vanguardismo andino elaborado por Churata con el vanguardismo europeo. Más bien trataré de aclarar las premisas epistemológicas detectables en el texto, recurriendo a una serie de conceptos filosóficos, antes de conectarlas con la literatura etnográfica andina, la cual ayudará a captar mejor la cosmología modelada en El pez de oro. Por eso, me dedicaré, en la segunda parte de este ensayo, al análisis del mito del Pez de Oro proveniente de la región del lago Titicaca, al que refiere el título del libro de Churata. En el curso de este análisis emplearé una metodología estrictamente estructuralista, porque la considero muy apta -hasta indispensable- para lograr un primer acercamiento a este texto. Quisiera subrayar sin embargo que, además del método estructuralista, son necesarias también metodologías postestructuralistas, hermenéuticas y fenomenológicas -a ellas recurro en otros capítulos de la monografía mencionada- para reconstruir el discurso del texto a analizar, ya que su heterogeneidad formal requiere una heterogeneidad metodológica que incluso logre combinar metodologías que, a primera vista, parecen excluirse.

LA EPISTEMOLOGÍA MONISTA DE EL PEZ DE ORO

“El hombre es todo en uno o no es” (108), escribe Churata en el primer capítulo de El pez de oro, para precisar después: “el alma [...] es la semilla en que el hombre está con su destino, su osaturo [sic], su intelección, su sistema neurovital, su kepi de existencias laceradas” (110). Pasajes como éste aparecen con redundancia en El pez de oro, lo que parece ser un medio retórico para fortalecer la fe en el catecismo salvador del libro, ya que la cita superior forma parte de un largo párrafo con el título programático "Paralipómeno Orkopata”. Refiriéndose a Spinoza y a Bruno $(90,111)$, Churata construye, a través del concepto del ahayu -alma indígena colectiva que, según la definición del autor, también es semilla y célula originaria ("Hay una especie de presencia en la tierra. Es la ahayu: la semilla”, 110)-, una teoría del monismo indígena, en la cual cuerpo y espíritu se entienden como una misma materia inseparable. Esta semilla con alma en la que se refleja todo el universo -codificado casi genéticamente- se asemeja bastante a la mónada de Leibniz en su variante indígena, ${ }^{2}$ y parece determinar toda la estructura de la obra churatiana.

\footnotetext{
${ }^{1}$ Agradezco el apoyo brindado por César Ángeles L. (Lima), Guillermo Ruiz y Francisco Olaso (Berlín) en la traducción del presente artículo al castellano que recoge parte del tercer capítulo de la monografía mencionada arriba.

${ }^{2}$ Leibniz es mencionado en dos pasajes de El pez de oro: "Todo esto corresponde a 'cargar el presente con el pasado’, que diría el barón de Leibnitz [sic]” (120) y “Miróme con ojos que dilataba la mónada de Leibnitz [sic]” (242). Mientras que Ortega y Gasset habla de la “resurrección de la mónada” (339), revalorizando a Leibniz (véase también el pasaje: "Entre la función separada de la sustancia, propia al pensamiento moderno, y la sustancia inactiva, mera potencia abstracta que el aristotelismo enseñó
} 
La construcción de este monismo se efectúa, desde luego, paralelamente al rechazo polémico del dualismo. La crítica de Churata se dirige, en primer lugar, contra Platón, que fue el fundador del modelo de representación dualista de "original” e "imagen”, el cual, a su vez, se ve inseparablemente vinculado con la dicotomía entre "cuerpo” y "espíritu”. En el párrafo "La caverna”, del largo prefacio "Homilía del Khori-Challwa”, Churata invoca la parábola platónica de la caverna; para él, la caverna -chinkhana ${ }^{3}$ en quechuaes conceptualizada como pars pro toto de Pachamama; es decir, como metáfora del útero en su función de instancia que genera la vida. Por eso Churata polemiza: "Entones la caverna del infinito no será el universo, ni el tiempo, ni la nada: será la vida. ¿Entiendes, Platón? Sólo se puede ser en mónada” (44). La propuesta platónica, que consiste en superar los fantasmas de la caverna a través de la filosofía para luego llegar al mundo de las ideas verdaderas, no es compartida por Churata que predica todo lo contrario:

Vivir en caverna, en la caverna y para la caverna, con el infracturable destino de la unidad vital, que no es más que el gozo de la fertilidad. Y como no se puede estar vivo y muerto, ni estar en dos naturalezas, ni objetiva y simultáneamente, estar en dos sitios, hay que estar en tensión láctea, que el punto de la tensión es el punto de la caverna. (45)

En El pez de oro, monismo y vitalismo coinciden, pues, en “unidad vital”. La sustancia con alma, de la que están hechos tanto el cuerpo como el espíritu, es -como ya he señalado- la semilla, el "licor seminal” (110), "la esperma que incendia la caverna" (152). Churata denomina la célula como un "individuo consciente" (349), que constituye al hombre no sólo física, sino también psíquicamente, puesto que "la semilla del hombre es su alma” (111). El alma, a su vez, es designada como “organismo sexual” (109); es decir, corporeidad y sexualidad, fertilidad y reproducción le son inherentes al vitalismo de Churata, proporcionando la base teórica de una estética (véase la fórmula churatiana “germinación como estética”, 35) que se manifiesta, por ejemplo, en la reanimación del haylli: una especie de poema o canción autóctona de origen prehispánico, en la que voces masculinas y femeninas se alternan, cantando el trabajo en el campo durante la siembra. Evidentemente, estas canciones destacan por su fuerte connotación sexual (Randall 28 ss.). La vida como “ser en mónada”, según la concepción de Churata, requiere entonces

a la Edad Media, cabe una excelente posición intermedia. La sustancia como fuerza; por tanto, como germen de acción. Ahora bien, esto es la mónada de Leibniz”, 343), toma distancia frente al filósofo alemán en un artículo llamado "Ni vitalismo ni racionalismo” (270-80) y publicado en la Revista de Occidente, la que-como es sabido-tenía amplia circulación entre los intelectuales latinoamericanos. Ahí, Ortega rechaza tanto el racionalismo de Leibniz como el vitalismo de Bergson, caracterizando al racionalismo, debido a los elementos antiteóricos, anticontemplativos y antirracionales que éste contiene en su opinión, como "misticismo de la razón” (280), porque asume una "actitud arcaica, impropia de la altitud de destinos a que la mente europea ha llegado". Para Churata, se le abre así el camino para reclamar -aunque sólo parcialmente- el racionalismo occidental dentro de su empirismo andino, en vez de lucharlo simplemente por medio de su escritura.

${ }^{3}$ En el castellano peruano coloquial, "chingana" designa una pequeña tienda donde se venden artículos diversos o un bar donde se come, se bebe y se baila. En un sentido más amplio, también se refiere a un burdel. 
unidad (“La condición ineluctable de la vida es la unidad”, 111), una unidad que se realiza a través de la unión corporal y que resulta discernible sintiendo. En este acto de sentir, el yo siempre se refiere recíprocamente a un tú, sin el cual el yo no puede existir:4 "Siente, siente, cada vez más. Allí sabrás que eres unidad porque en ti en todo momento se fragua utilidad. Soy en cuanto son; y son porque soy; y porque somos es posible el ser. Sólo porque me eres útil eres” (348). Este acto de sentir al otro resulta fundamental para que Churata pueda construir el yo como parte integral de un colectivo. El "ego" hay que comprenderlo como un tú múltiple ("Ego: tú-multo. [...] Tú eres Naya”, 3495) que coincide con el universo ( “Soy pues el Universo: el Universo es sólo ‘ego””, 348). ${ }^{6}$ De esta manera, a Churata se le abre el camino para poder universalizar su experiencia individual: el yo del autor que se lamenta de la muerte de su hijo, ${ }^{7}$ siempre dirigiendo la palabra a éste -a un tú al que inquiere el yo del autor-corresponde con la preocupación supraindividual del yo-narrador de El pez de oro acerca de la reanimación de la cultura incaica; es decir, a la fórmula “Tú eres Naya” le es inherente la idea de una mónada, en cuanto se puede afirmar una vez más, con las palabras de Nicolai Hartmann, la tesis de Leibniz que dice que "cada

${ }^{4} \mathrm{El}$ concepto de la "reciprocidad", forjado por John V. Murra, sigue vigente hasta hoy en la antropología andina, describiendo muy acertadamente las estructuras sociales de los quechuas y aymaras. La misma relación de reciprocidad también se observa con respecto a la dualidad de los sexos que aspiran a su unificación: "El problema que presentaba la dualidad de sexos era el de reconciliar la división con la unidad a nivel de las parejas humanas. Se encuentra el mismo problema al nivel de mitades endógamas. En ambos casos se puede apreciar ahora que Dos se consideran unificables solamente si se elimina la mediación: en el caso de las parejas humanas la mediación mínima se da en la cópula; en el caso de las mitades, se hace un paralelo a través de la cópula ritual regulada en la hostilidad institucionalizada” (Platt Espejos 42).

${ }^{5}$ Naya: "yo" en aymara. Con respecto a la diferencia que hace Churata entre el yo y el ego como un tú múltiple, hay que anotar que una diferenciación parecida se efectúa en la gramática misma de los idiomas indígenas. El quechua emplea -tanto como el aymara- dos modos del verbo en la primera persona plural: el inclusivo, incluyendo la primera, segunda y tercera persona singular (ñuqanchik: "nosotros todos") y el exclusivo que unifica la primera y la tercera persona, excluyendo la segunda (ñuqayku: "nosotros”). En otro lugar, Churata define el ego a través de la fórmula: "El [pez de oro] + Naya = Ego" (128).

${ }^{6}$ Nótese la coincidencia con la vanguardia antropofágica brasileña, pues se lee en el Manifesto Antropófago: "Morte e vida das hipóteses. Da equação eu parte do Cosmos ao axioma Cosmos parte do eu. Subsistência. Conhecimento. Antropofagia” (Andrade 15). Con respecto a las paralelas entre Churata y los antropófagos véase también nota 28.

${ }^{7}$ No hay que olvidarse de que, para Churata, el Pez de Oro también es la reencarnación de su hijo muerto Teófano; abundan los pasajes que confirman tal interpretación a lo largo del texto. La afinidad de vitalismo y mortalismo en Churata se produce, visto así, por hechos biográficos fatales. Estos hechos son condensados en una carta dirigida a Mariátegui datada el día 24 abril de 1929. La cita Pantigoso: "Debe usted estar extrañado de mi silencio de tantos días. Pero es que la VIDA, así con mayúsculas, sigue atacando mis izquierdas revolucionarias y se ha propuesto dejarme limpio el camino de todos los seres que eran mi legado de alegría. Ayer fue Teófano Churata, le siguió Quemensa Churata, mis hijos, y el 12 de abril a las cinco treintainueve minutos de la madrugada, Brunilda mi compañera, chiquilla que con quince años floridos vino desde Chile a pagar mi tributo a la tierra. Fácil es que piense que tanto golpe si me ha endurecido el cuero me ha puesto también muy deslucida el alma” (47). 
formación en proceso de ser 'representa’ de alguna manera el sistema entero” (Hartmann 318, mi traducción). En una serie de artículos que se publicaron en 1949 en el suplemento literario del diario paceño Última Hora bajo el título Problemas ontológicos, Churata invoca explícitamente a Hartmann:

Otro modo de entender la realidad está en la identificación de lo real con las cosas, todo lo físico, lo material, lo orgánico habrá de ser entendido como real y viceversa, todo aquello que carezca de este carácter físico habrá de entenderse como irreal. En el hombre sólo su corporeidad formaría su realidad, de tal suerte que los sentimientos, las acciones y toda la vida espiritual del hombre, su propio destino, todo aquello que la humanidad ha considerado como real, todo aquello no formaría parte de la realidad del hombre. Este es un concepto materialista que se debe rechazar (opina Nicolai Hartmann a quien estamos analizando). "El único concepto adecuado de la realidad es el que ciñe a los fenómenos, y sólo es un concepto de realidad adecuado al fenómeno cuando abraza lo material y lo inmaterial”. (citado por Gonzáles Fernández y Ríos Moreno 87)

Refiriéndose a Hartmann, Churata subraya la necesidad de un lazo entre cuerpo y espíritu que hace recordar el tinkuy andino -la unidad de los contrarios-, un lazo que “abraza lo material y lo inmaterial”. Aunque critique la equiparación del pensamiento con el ser, Hartmann no abandona la separación entre conciencia y sujeto. Puesto que la conciencia es “insuperablemente cautiva en sí misma” (315, mi traducción), el sujeto tiene que poder salir de sí mismo para discernir al objeto, al otro, al tú. Sin embargo, para este propósito, el sujeto "ya tiene que estar determinado por el objeto; éste ya tiene que haber generado su imagen en el sujeto” (317, mi traducción); es decir, sujeto y objeto son -así como “ego" y “tú-multo"-, inmanentes a sí mismos, aunque lo sean sólo parcialmente. Lo que propaga Churata en El pez de oro es, pues, un "sujeto centrado, un sujeto de la modernidad” (Gonzáles Fernández y Ríos Moreno 87). Sin embargo, el único ser centrado, según la fenomenología antropológica de Helmuth Plessner, es el animal, mientras que la posición humana se caracteriza justamente por su excentricidad, ya que el hombre “no sólo es únicamente cuerpo, ni tiene únicamente cuerpo” (241, mi traducción, énfasis en el original), así que nunca logrará un verdadero equilibrio entre ser cuerpo y tener cuerpo, es decir entre cuerpo y espíritu. Sólo a través de la equiparación del sujeto indígena con un animal (“El indio es la bestia del Ande”, El pez 19), le resulta posible a Churata afirmar esta centricidad utópica, cuyo símbolo es el perro que se llama Thumos y que reaparece varias veces en El pez de oro. Esto posibilita la anteposición discursiva del instinto animal a la racionalidad del hombre civilizado:

Thumos me introdujo al respeto de la bestia; y no porque en él identificara el alma platónica del animal, sino porque en él descubrí una humanidad libre de las deshumanidades del hombre.

Pensé que el del hombre no es el lenguaje más activo y el más musical menos. El ladrido en animales superiores como Thumos qué riqueza de tonos no tiene. [...] el ladrido del perro, o el trino del pajarillo, no son meras voces más o menos armoniosas: son expresión de sensaciones, sentimientos, deseos, medios de comunicación; verdadero lenguaje. Y para que estos animales irracionales puedan entenderse es preciso que posean una 
sutileza auditiva que no todo los hombres tienen. [...] El lenguaje del hombre es de estructuras verbales; la [sic] del pajarillo de estructura melódica. Capitán: ¿es que los irracionales poseen la razón musical? (377)

En la base de esta misma dialéctica entre tener cuerpo y ser cuerpo, Churata ubica también el acto de escribir. Éste no es un acto incorporal del pensamiento individual, sino un escribir con el cuerpo y con la naturaleza:

\begin{abstract}
Si yo viviera con la cabeza, y con la cabeza pensara, me creería un animal detenido. Yo pienso con la rodilla, con el tendón, el codo, la oreja, el hígado. Cada parte de mi cuerpo posee la facultad de pensar, discernir, crear. Y si mucho me hurgas, te diré que pienso con los árboles, los ríos, las nubes, los piojos, el rayo... Cómo pudiera hacerme escritor... Verás lo que es escribir con los huesos, la nariz, el mentón, los compagnones [sic], como dicen los franceses; con el cuerpo íntegro. Esos poetillos narcisos que se miran la frente seguros de que tras ella hace brujeríos [sic] un Merlín milagrero, me provocan risa. El hombre para ser tal viva sabiendo que ninguno de sus pensamientos o acciones, a no ser los hijos purulentos, son creatura del cerebro, sino veces del riñón, otros de los sartorios, del pubis, del plexo solar, las más del diafragma. (202)
\end{abstract}

Desde luego, Churata intenta realizar este monismo, que he tratado de esbozar sinópticamente, también en el nivel formal de El pez de oro. El reproche de que el libro es caótico, ilegible, de que carece de cualquier estructura, resulta entonces insostenible. Tanto Huamán como Pantigoso trataron de reconstruir la estructura de El pez de oro; para este propósito, parten del subtítulo del libro: Retablos del laykhakuy. ${ }^{8}$ Mientras que Pantigoso convierte la palabra "retablo" en "red que habla” (251) -la red parece una metáfora legítima para describir la estructura de El pez de oro, ya que el Pez de Oro queda cautivo en ella, así que puede ser observado y analizado de más cerca-, Huamán conecta los “retablos” con el dibujo cosmológico en la crónica de Santacruz Pachacuti, ${ }^{9}$ atribuyendo

\footnotetext{
${ }^{8}$ El neologismo laykhakuy, formado de layk[h]a y de los sufijos - ku e -y, se traduce -según Churata (El pez 545)- como "[c]aminos de acción de la voluntad mágica".

9 Jan Szeminski analiza detalladamente en su monografía Un kuraca, un dios y una historia la crónica de Santacruz Pachacuti, enfocando -entre otros- el personaje llamado Tunapa, del que se dice que había evangelizado a los indígenas -o por lo menos les había enseñado una nueva religión (ley) - ya mucho antes de la llegada de los españoles (de una manera parecida, pues, a como lo hace el Khori-Challwa del mito churatiano, siendo éste un pez y, por ende, un símbolo de la cristiandad). Tunapa parece entonces un mensajero profético de la fe cristiana o una especie de mesías que realiza milagros al acabar con el régimen de los hapi ñuñus demoníacos, provocando un pachakuti (así como también es provocado uno por el Pez de Oro al final del mito a analizar en la segunda parte de este artículo; véanse también las notas 12 y 31). Churata, a su vez, escribió un ensayo titulado "Thunapa en el vértice del humanismo" (Diez de Medina 393); además, menciona el nombre de Tunapa (o 'Thunapa') dos veces en El pez de oro: la primera vez se refiere a la obra del mismo título de Fernando Diez de Medina (532); la segunda vez, el personaje aparece en el contexto de las crónicas ("señálase en Thunapa la presencia de apóstol de Jesús tras el Espolio”, 28). Por eso, hay que relacionar el Tunapa de Churata con el personaje de la crónica de Santacruz Pachacuti, cuyo credo cristiano incluye tanto las deidades incaicas (el sol, la luna, el rayo, etc.) como el dios cristiano uno y trino:
} 
a los distintos capítulos o retablos del libro -a menudo un poco arbitrariamente- las significaciones de "Viracocha" (capítulo uno: "El pez de oro"), "sol” (capítulo dos: "Españoladas”), "luna” (capítulo tres: "Pachamama”), "abuelo” (capítulo cuatro: "Pueblos de piedra”), "abuela” (capítulo cinco: "Mama Kuka”), "tierra” (capítulo seis: "Puro andar”), "laguna” (capítulo siete: “Los sapos negros”), "hombre” (capítulo ocho: “Thumos”), “mujer” (capítulo nueve: “Morir de América”) y “Colcapata” (capítulo diez: “EL PEZ DE ORO”) (53 ss.). Aunque estas interpretaciones no carecen de plausibilidad, a ambos autores se les escapa el punto clave.

El mismo Churata llama la magia del layka -del chamán o curandero del subtítulo de El pez de oro- una magia monista ("monismo del layka”, 101), ya que lo sobrenatural, tanto para el layka como para el pueblo indígena, se presenta como "completamente natural” y forma parte de la vida cotidiana fuera de la cual no existe otra realidad más verdadera. ${ }^{10}$ Aunque se puede constatar en el subtítulo también una probable referencia al “Retablo del Maese Pedro" de la segunda parte de Don Quijote, ${ }^{11}$ es el monismo del layka

“[...] la santa madre Yglesia rromana lo cree lo que yo Don Juan de Santa cruz lo creo, y así en ella quiero bibir y morir en el temor de Dios trino y uno que bibe y rreina para siempre sin fin. Como digo, creo en Dios trino y vno, el cual es poderoso Dios que crió al cielo y tierra y a todas las cosas en ellas questan, como el sol y luna, estrellas, luzeros, rrayos, rrelámpagos y truenos, y a todos los elementos, \&; y luego crió al primer hombre Adan, Eva, su mujer, y simijanza, progenitor del género humano, \&, cuya deszendençia somos los naturales de Tauantinsuyo, como los demás naçiones que están poblados en todo el uniberso, mundo, así blancos como negros”(Santacruz Pachacuti Yamqui 282). Nótese el juego de palabras que hace Churata con "trino" relacionado por una parte a la Trinidad, y por otra al sonido onomatopoético del Pez de Oro, cuando éste aprende a volar como un pájaro (véase nota 31 y la segunda parte de este ensayo). Este juego de palabras reaparece varias veces a lo largo de El pez de oro, adoptando casi un status de leitmotiv, y puede haber sido generado al acordarse Churata de la fórmula de invocación subversiva en Santacruz Pachacuti.

${ }^{10}$ Son evidentes aquí las alusiones al concepto del "realismo mágico" -o más bién al de lo "real maravilloso" en el sentido que le da Carpentier, en la medida en que la primera noción remite al crítico de arte alemán Franz Roh que la utilizó para designar una dirección de la pintura postexpresionista alemana, antes de que fuera recogida por Arturo Uslar Pietri y por Ángel Flores en la crítica literaria latinoamericana. Explicítamente, Aramayo califica a Churata de precursor del realismo mágico.

${ }^{11}$ Después de que Churata, en la segunda oración de El pez de oro, invoca -como una especie de introitum - a Cervantes (9), alude al retablo de Maese Pedro al especular si el empirismo andino vale más que el racionalismo europeo (123). En Cervantes, Don Quijote toma el escenario teatral del retablo por la realidad, por lo que decapita con su espada las muñecas del Maese Pedro, que representan moros: "Y, diciendo y haciendo, desenvainó la espada y de un brinco se puso junto al retablo y con acelerada y nunca vista furia comenzó a llover cuchilladas sobre la titerera morisma, derribando a unos, descabezando a otros, estropeando a éste, destrozando a aquél; y entre otros muchos, tiró un altibajo tal, que si maese Pedro no se abaja, se encoge y agazapa, le cercenera la cabeza con más facilidad que si fuera hecha de masa de mazapán” (capítulo XXVI). Comportándose así, Don Quijote le parte el cráneo no solamente al rey morisco Marsilio, sino también -aunque por error-a Carlomagno. Está entonces presente en El pez de oro un motivo que remite a la decapitación y al regicidio, aludiendo quizás al asesinato de Atawallpa por los españoles, ya que la reconquista contra los moros se ve alargada por la conquista de de los reinos de los aztecas e incas. Hace recordar también el mito conocido del Inkarrí, recogido por Arguedas, que parece combinar elementos de la 
lo que prevalece y determina la estructura de El pez de oro hasta en el detalle. Hay que comprender los distintos capítulos, entonces, como mónadas que reflejan el universo de El pez de oro según su propia manera característica e inconfundible. Tanto la redundancia de la argumentación, la permanente repetición de los motivos que son variados, como la congruencia de dos capítulos -el primero (“El pez de oro”) y el último (“EL PEZ DE ORO”)- en cuanto a sus títulos, los que, a su vez, coinciden con el de la obra entera, se explican así fortaleciendo la probabilidad de tal interpretación. Como demuestro en otro lugar (Bosshard 83-6), el primer capítulo de El pez de oro ejerce una especie de función generadora, que consiste en establecer un trasfondo de motivos y de tópicos indigenistas. Es por eso que la estructura monista hallada en el texto se esclarece mejor analizando este mismo capítulo, "El pez de oro”, porque contiene en nuce todas las temáticas relevantes que son expandidas y profundizadas en los capítulos siguientes. Allí están la fertilidad, que es motivo del capítulo "Pachamama"; la violencia de la conquista y de la colonia, que se corresponde con "Españoladas”; la mitología andina ("Pueblo de piedra”), la medicina y el chamanismo andino ("Mama Kuka”), el mundo de los muertos ("Puro andar"), la pérdida del hijo ("Los sapos negros”), el indio como bestia (“Thumos”) y también el intento sintetizador de fundar un estado indígena ("Morir de América”). Visto así, "El pez de oro” aparece, si uno piensa en la doctrina de las mónadas de Leibniz, como la divina mónada originaria, la que genera todas las demás; así que la asociación de Huamán de este capítulo con "Viracocha" ya no se presentaría tan arbitraria.

"El pez de oro" termina con el mito literaturizado del Khori-Challwa, del Pez de Oro, también conocido como el "Príncipe Suchi”. Este mito proveniente de la región del lago Titicaca no había sido -hasta donde se sabe- fijado nunca por escrito, por lo que resulta imposible averiguar en qué medida Churata lo transformó al trasladarlo a la literatura. Sin embargo, el nacimiento del Pez de Oro como el resultado de una relación amorosa entre un puma y una sirena se corresponde con toda una serie de iconografías precolombinas: relaciones entre mamíferos de presa y anfibios parecen señalar siempre el ocaso del mundo viejo y el comienzo de una nueva era; es decir, el pachakuti. ${ }^{12} \mathrm{Si}$ mis premisas, en lo que

decapitación de Tupaq Amaru con aquellos de la degollación de Atawallpa, tanto como la anónima Tragedia del fin de Atahualpa y la descripción de la muerte de Atawallpa en Huamán Poma de Ayala, puesto que los tres relatos - el mito, el teatro y la crónica- coinciden en que el inca es decapitado, en vez de ser degollado, como demuestran los hechos históricos. Al referirse al retablo del Maese Pedro, convirtiéndolo en los Retablos del laykhakuy, Churata posiblemente trata de sugerirnos la vuelta del inca, la que se realizará, como es sabido, cuando su cabeza se haya reunido con el cuerpo bajo la tierra; es decir, Churata parece participar también en la reescritura del mito del Inkarrí y de la utopía andina (véase Flores Galindo).

12 "Los dos animales fabulosos, uno terrestre y otro acuático, [...] [a]parecen anunciando los Pachacuti, los cambios de un tiempo al otro, de una región a otra, de un poder [a] otro [...] Por un lado, los ‘colmillos' y las 'serpientes' caracterizan a los ancestros en los imágenes mochicas y andinas, y por otro lado, es el camay, las fuerzas vitales que animan, que caracterizan los camac, las huacas, los ancestros, en los textos del siglo XVI y xVII así como hoy en día. Si nuestras interpretaciones son justificadas, los ‘colmillos’ y las ‘serpientes’ serían entonces representaciones icónicas de las fuerzas que animan, y el camay correspondería a la nación de poder inmortal de los ancestros” (Hocquenghem Iconografía 185 y 208). 
concierne al capítulo "El pez de oro", son correctas, se puede suponer que este mito contiene las claves para la comprensión del texto. Por eso lo analizaré cuidadosamente, con todos los recursos que proporciona el estructuralismo, en los párrafos siguientes.

\section{Análisis del mito del Pez de Oro}

Existen ciertamente reservas que no se pueden pasar por alto relacionadas con el recurso al estructuralismo para analizar el mito del Pez de Oro. La problemática de tal procedimiento consiste sobre todo en el intento de aplicar criterios racionales a un texto como El pez de oro, que tiene fama de alógico y desestructurado, ya que la terminología postestructuralista -como lo demuestra la monografía de Huamán- logra captar su discurso de una manera mucho más adecuada. Pero si las observaciones de Huamán son ciertas, si la escritura de El pez de oro de hecho deconstruye el logocentrismo occidental, sólo es capaz de hacerlo utilizando los medios propios de éste. Ello implicaría, a su vez, que el logos sigue operando -aunque esté escondido, desterr(itorializ)ado ${ }^{13}$ y desechadobajo la superficie del texto, posibilitando de esta manera un análisis que se basa en una racionalidad que -aunque no coincida con la racionalidad occidental-sí es racionalidad, en tanto sería un signo de ignorancia afirmar que las estructuras sociales y las creencias míticas de los pueblos indígenas carecen de racionalidad. ${ }^{14}$ Conscientes de que al recurrir al estructuralismo se corre, a veces, el peligro de racionalizar demasiado el asunto, haciendo hincapié en el logocentrismo y etnocentrismo occidental, ${ }^{15}$ nos parece, sin embargo, que tal procedimiento es legítimo, tomando en cuenta especialmente la escasez de alternativas viables. Por otro lado, queda claro que el mismo mito-análisis estructuralista desarrollado por Lévi-Strauss encierra en sí -a pesar de su gesto objetivista- una problemática que no se puede obviar: una tendencia que, a menudo, favorece perspectivas

\footnotetext{
${ }^{13}$ Además de los conceptos estructuralistas, parece muy útil la terminología postestructuralista de Gilles Deleuze y Félix Guattari. Aparte de la noción de “desterritorialización”, quisiera proponer el uso del concepto "rizoma” para describir de una manera más adecuada el carácter de El pez de oro (Bosshard 120-9), dado que el término implica "un tubercule agglomérant des actes très divers, linguistiques, mais aussi perceptifs, mimiques, gestuels, cogitatifs: il n’y a pas de langue en soi, ni d'universalité du langage, mais un concours de dialectes, de patois, d'argots, de langues spéciales" (14). Nótese que el mismo Churata utiliza la palabra "rizoma” en un pasaje que coincide con las conclusiones de la primera parte de este artículo con respecto al vitalismo monista del autor: “¿Y qué es lo que siente en el hombre? ¿Las rizomas cerebrales en sí, por sí? Hay una conciencia que polariza el organismo y cuando ella falta éste se detiene; tan es funcional que cualquier embolia puede determinar su atrofia y, consecuentemente, la muerte legal. Se entiende así que el hombre es hombre en esa función, y que nada de cuanto es puede venirle sino de ella” (91, énfasis mío).

${ }^{14}$ Lo mismo vale para el mito, el cual no debe ser entendido necesariamente como antípoda del logos. Blumenberg escribe que la antitésis romántica de "mito y racionalidad es una invención tardía y mala, porque renuncia a concebir la función del mito para la superación de esa extrañez arcaica del mundo como algo racional, lo más anticuados parezcan sus medios a posteriori” (56, mi traducción). Con respecto a la racionalidad andina véase Golte.

${ }^{15}$ Véase la crítica de Derrida en el marco del ensayo "Die Struktur, das Zeichen und das Spiel im Diskurs der Wissenschaften vom Menschen”.
} 
reduccionistas e incluso cierta arbitrariedad interpretativa. Por eso, el mismo Lévi-Strauss indicóque el estudio de los mitos no puede realizarse sólo según criterios meramente racionales -de esta manera, el predominio del logocentrismo en el análisis se ve cuestionado y relativizado-, designando su metodología con el término bricolage, el cual supone una especie de pragmatismo intelectual, que hace uso de todos los medios auxiliares disponibles para resolver el problema en cuestión.

Mi selección de instrumentos y medios auxiliares para llegar a una interpretación coherente del mito de Pez de Oro se ha efectuado entonces cn este mismo pragmatismo vinculado a la idea del bricolage tiende a independizarse, falsificando así sus propios resultados- hay que evitar el intento de escencializar las conclusiones de tal análisis , para mantener siempre una distancia crítica frente a ellas. Siguiendo libremente el análisis que realiza Greimas del mito de referencia Bororo de Le cru et le cuit ${ }^{16}$ de Lévi-Strauss, intentaré estructurar el mito del Pez de Oro en secuencias narrativas para luego elaborar sus funciones respectivas, teniendo en cuenta especialmente los estudios de Zuidema fundamentales para la antropología peruana, ya que tratan de transferir la metodología lévi-straussiana desarrollada en el Brasil al espacio andino.

Churata nos narra el mito del Khori-challwa en cuarenta y seis párrafos enumerados por el mismo autor. Se observan seis secuencias o episodios, los que marcan -en la terminología de Greimas- el tránsito de un contenu inversé, al que pertenecen las primeras tres secuencias, al Contenu posé, el que encierra en sílso últimos tres episodios. Esta inversión -aunque parece ser una característica general del récit mythique- es el aspecto que más llama nuestra atención, en la medida en que conecta con el concepto del kuti o pachakuti, que juega un papel importante en el mito a analizar. El desarrollo sintagmático del mito puede resumirse de esta manera:

\begin{tabular}{|c|c|c|c|c|c|c|}
\hline \multicolumn{7}{|c|}{ récit mythique } \\
\hline \multirow[t]{2}{*}{ contenu } & \multicolumn{2}{|c|}{ contenu inversé } & & \multicolumn{3}{|c|}{ contenu posé } \\
\hline & correlé & \multicolumn{2}{|c|}{ topique } & \multicolumn{2}{|c|}{ topique } & correlé \\
\hline $\begin{array}{l}\text { séquances } \\
\text { narratives }\end{array}$ & \begin{tabular}{l}
\multicolumn{1}{c}{ I } \\
Comienzo: \\
árbol genea- \\
lógico del \\
Khori-Puma \\
$1-6$
\end{tabular} & \begin{tabular}{l}
\multicolumn{1}{c}{ II } \\
Las tres \\
novias, \\
Khesti-imilla \\
7-9
\end{tabular} & $\begin{array}{l}\text { III } \\
\text { Muerte } \\
\text { del Khori- } \\
\text { Challwa } \\
\text { 10-13 }\end{array}$ & \begin{tabular}{l}
\multicolumn{1}{c}{ IV } \\
Duelo, \\
la lágrima \\
del Khori- \\
Puma \\
14-20
\end{tabular} & $\begin{array}{l}\quad \text { V } \\
\text { Renacimiento } \\
\text { delEl alba, } \\
\text { Khori-Challwa } \\
\text { 21-30 }\end{array}$ & $\begin{array}{l}\text { VI } \\
\text { Final: } \\
\text { la Aurora } \\
\text { 31-46 }\end{array}$ \\
\hline Faliaios (vers.) & & & & & & \\
\hline
\end{tabular}

En la secuencia inicial I (párrafos 1-6) se introduce primero el lago Titicaca -origen y cementerio de todas las culturas andinas-, en el fondo del cual viven los antepasados de toda la población del Altiplano en forma de chullpa-tullus ("Lago de los antiguas

\footnotetext{
${ }^{16}$ Aunque la crítica de Cornejo Polar frente a la metodología de Greimas (“útil sí, pero tan capaz [...] de verificar lo previamente evidente como probar lo imposible”, 235) esté justificada-posiblemente, el análisis del mito del Pez de Oro probará también algo que a un lector andino le parecerá evidente desde el principio-, sigue siendo un instrumento bastante eficaz.
} 
Chullpas”, 129), ${ }^{17}$ habitando el mundo inferior de la ukhupacha. Al designar el lago con el nombre "Tata Titikaka”-siendo éste una deidad (achachila) de color esmeralda-el lago subyace un proceso de antropomorfización, por lo que puede comunicarse con el KhoriPuma ("Puma de Oro"), el padre del Khori-Challwa. El puma, a su vez, es descrito como un ser sucio y feo que mora en una caverna (chinkhana). A continuación, se explica su árbol genealógico, por lo que queda claro que su antepasado más remoto había vivido en las aguas del lago Titicaca durante cierto tiempo ("Puma de agua su awichu-auki”). ${ }^{18}$ De él proceden tanto el bisabuelo Punka-hokho como el abuelo Puma-sakha y el padre del Khori-Puma, el Puma-khala. ${ }^{19}$ La cadena genealógica enlaza de esta manera los elementos agua-lodo-totora-piedra-oro, aludiendo a una disyunción entre el agua (Puma de agua, Puma-hohko) y la tierra (Puma-khala, Khori-Puma), ${ }^{20}$ por la que el Puma-sakha ocupa, morando en la totora del lago Titicaca, una posición intermediaria que marca el proceso de tránsito del agua a la tierra. El Puma de Oro le informa al Tata Titikaka acerca de su ascendencia ("naya, he vivido en el Agua, en la Sakha, en el Rumi, ${ }^{21}$ en el Hokho") y le pide la mano de su hija. Éste, indeciso aún, le propone al Khori-Puma-después de haberle recordado que lo tutee para que nadie lo tome por un werakhocha ${ }^{22}$-en el episodio II (párrafos 7-9) casarse con la Khellwa, una especie de gaviota. Sin embargo, el Khori-Puma

\footnotetext{
${ }^{17}$ Chullpa significa "tumba” y chullpar, “cementerio". Véase también Platt: "De acuerdo a estos mitos [relativos a la población preincaica], la gente que vivió antes de los Incas se llamaban Chullpas. [...] Se cree que en el tiempo de los chullpas los hombres y los animales eran en alguna forma 'lo mismo'; esa época es conocida como el 'tiempo inquieto' (inkitu timpu) porque los hombres y las bestias intercambiaban sus formas fácilmente. [...] Más aún, la era de los chullpas era la 'edad de oro’ de la mitología macha, anterior a la domesticación de animales y plantas [...] Esto encaja con la asociación [...] con un 'estado de naturaleza' y un estado 'presocial', donde existía continuidad entre los hombres y los dioses y el único principio de organización era el natural y primordial basado en las diferencias sexuales. Los incas, al establecer el sistema de mitades, fundaron con ello un sistema social que fue para la 'era anterior' semejante a lo que la domesticación de animales y plantas habría sido para el estado 'pre-existente’ de productividad natural. La división entre Aransaya y Urinsaya puede, por consiguiente, considerarse como un substituto socio-simbólico del principio 'pre-social', necesario para la regulación de las relaciones sexuales y matrimoniales, único principio a través del cual puede constituirse la sociedad. 'El Hombre y la Mujer’ es aún ahora la dualidad fundamental de acuerdo a la cual se organiza la sociedad, pero se ha proyectado además a un nivel de instituciones sociales y de simbolismos, en el que a través de las mitades endógamas, se ha reemplazado el estado de 'promiscuidad natural' que lo había precedido“ (24 ss.)

${ }^{18}$ Pantigoso anota que en aymara titikaka significa "puma de piedra" (19).

${ }^{19}$ Hokho (ay.) significa "lodo", sakha (ay.) "totora” y khala (ay.) "piedra”.

${ }^{20}$ Este tránsito del agua a la tierra se aclara aun más tomando en cuenta las conotaciones de los elementos respectivos. Así, se puede deducir que agua $=$ agua $/$ tierra, lodo $=$ agua $\cup$ tierra, totora $=$ tierra $\cup$ agua, piedra $=$ tierra $/$ agua.

${ }^{21}$ Rumi (qu.) = khala (ay.) = "piedra".

22 “ No me voznees tan feo, Khori-Puma: pareces un werakhocha!...” (130) Wera-khocha es -además de que los indígenas llamaban así a los españoles- el nombre de una deidad que está en oposición al dios solar. Por eso, werakhocha parece menos vinculado al cielo, sino mucho más a la tierra habitada por el Khori-Ouma; al mismo tiempo contiene el sustantivo khocha ("lago"), así que está asociado, en general, con hurin, es decir con la parte inferior del mundo. Acerca de la etimología de la palabra véase Szeminski 17 ss.
} 
no está de acuerdo, porque, según él, la gaviota siempre vuela en las alturas del cielo, por lo que podría olvidarse de su esposo ("la Khellwa es una bulliciosa airada, te cultiva poco cariño”, 130). Por eso, considera casarse más bien con la Kheñula, un ave acuática. Pero después de haberlo pensado brevemente, el Puma también la rechaza, porque a su parecer, también ella pasa demasiado tiempo en el aire, encontrándose en el agua sólo para pescar, refugiándose luego en las alturas. Entonces, el Khori-Puma desea una esposa que resida en el lodo del lago ("Deseo esposa hogareña que anide en el lodo de tus hermosos palacios”). Al escuchar esto, al Tata Titikaka se le ocurre solamente la Khesti-imilla (“chica resplandeciente"), una sirena con escamas de plata que, sin embargo, mora en el Lago de Arriba, es decir en el cielo ("vive lejos, al otro lado de mis ojos”). ${ }^{23}$ El hábitat de las tres posibles novias del Khori-Puma se traslada entonces en un eje vertical desde arriba hacia abajo, desde las alturas airadas de la Khellwa $\in$ cielo pasando por el dominio de la Kheñula $\in$ agua $\cap$ cielo hasta la Khesti-imilla $\in$ agua $\cup$ cielo, ser parecido a un pez que mora en el agua del lago, el que -paradójicamente- está ubicado en el cielo. Es decir, la sirena habita al mismo tiempo los espacios de arriba y abajo, incluso más allá del dominio de la Khellwa.

Considerando que los tres mundos de la cosmovisión indígena, la kaypacha, el mundo real (la superficie de la tierra y del agua), la ukhupacha, el mundo bajo la tierra (la chinkhana y el chullpar en el fondo del lago Titicaca) así como la hananpacha (el cielo) constituyen la dicotomía hurin (ukhupacha) vs. hanan (hananpacha), es decir una oposición entre abajo y arriba, ${ }^{24}$ siendo la kaypacha el área fronteriza entre ellos, se atribuye a la Khellwa el hanan, a la Kheñula hanan y, en parte, también hurin, tanto como hanan y hurin a la Khesti-imilla, porque ésta recuerda por sus escamas de plata un ser o una constelación estelar; ${ }^{25}$ en cambio, al Khori-Puma le corresponde el hurin únicamente. Con respecto a la estructura social del Tawantinsuyu, el Khori-Puma pertenecería entonces -para emplear la clasificación de Zuidema- a Cayao, la Khellwa a Collana, la Kheñula a Payan y la Khesti-imilla, finalmente, a un cuarto grupo en el que están subsumidos los sirvientes de la estirpe real, los antepasados comunes a todos los habitantes

\footnotetext{
${ }^{23}$ A través de este pasaje se aclara la función reflejadora del lago Titicaca, a la cual alude Churata en otro lugar: "[...] El pez de oro está labrado con materiales puneños, radicalmente fruto de las reacciones anímicas telúricas de nuestra tierra y su lago, entendido, que si el Titikaka se refracta en el cielo, hay que convenir que el cielo de nuestra tierra es sólo el Titikaka proyectado a las esferas" (Antología 14).

${ }^{24}$ Véase al respecto Hocquenghem Hanan, que coincide-aunque con variaciones-con la introducción a Hocquenghem Iconografía. La dicotomía entre arriba y abajo, idéntica a aquella entre hombre y mujer, determina también las estructuras económicas y agrarias andinas, en la medida en que ciertas plantas útiles y tubérculos sólo se cultivan en determinados niveles de altura, así que los campesinos tienen plantaciones en distintos "pisos ecológicos" al mismo tiempo. Murra caracterizó este sistema con la noción de "verticalidad" (427-76).

${ }^{25}$ El cielo de noche -al contrario del cielo durante el día- es asociado normalmente con hurin, porque en la noche todas las cosas se invierten: "En la noche, el mundo al 'revés', el poder está representado por el señor de las tinieblas que se opone al sol. [...] Las posiciones de hanan y hurin se invierten" (Hocquenghem Hanan 20). Hay que relacionar, pues, la Khesti-imilla como un ser que mora en el cielo de noche con hurin, a pesar de que pertenezca topográficamente a la hananpacha.
} 
del Tawantinsuyu -los chullpas-, pero también la población originaria del Cuzco a la que Zuidema concede tanto características de Cayao como de Collana. ${ }^{26}$

En la secuencia III, última del contenu inversé (párrafos 10-13), el Khori-Puma se enamora de la sirena procedente del Lago de Arriba y la desposa. El Tata Titikaka le profetiza que ella dará a luz al "Hijo Inmortal”, “el primero que sepa de dónde vino y va donde sólo para Él andan los caminos” (130), y al mismo tiempo le hace la advertencia de no devorarlo: “¡Si te lo comes, te comerá!...” -pronunciada en vano, como se verá: “Vers. 12. Pudo el Puma con el hambre de su diente, y enloquecido por el Oro, se comió a su hijo; día postrer, loco para la miel de la Moksa, ${ }^{27}$ se comió a su Khesti”. Incluso antes de que el narrador hubiera descrito el nacimiento del Pez de Oro, el Khori-Puma ya devora a su hijo tanto como a su esposa, la sirena -posiblemente en estado de excitación sexual ("loco para la miel de la Moksa”). Por este acto cruel y bárbaro, la caracterización del puma, en analogía con el jaguar de Lévi-Strauss, por medio del adjetivo cru o crudo -uno ya habrá presentido algo así- se ve confirmada. Sin embargo, se debe enfatizar que la unión de la tierra con el agua y el cielo recién se da a causa de este acto de incorporación caníbal; ${ }^{28}$

${ }^{26}$ Collana designa, según Zuidema (119), la nobleza incaica, Cayao la población común y humilde, y Payan los mestizos de matrimonios exogámicos entre Collana y Cayao. Collana residía en Hanan Cuzco, la parte superior de la capital incaica, Payan y Cayao, en cambio, en Hurin Cuzco, el barrio inferior central de la ciudad. Ya que también en el mito del Pez de Oro las relaciones familiares y la geneología juegan un papel importante, nos parece adecuado el empleo de estas nociones que Zuidema tomó de las crónicas. Los incas se consideraban los hijos del Titicaca, como demuestra el mito de la fundación del Cuzco, el mito de los hermanos Ayar (Churata lo menciona, insinuando paralelismos con el mito del Khori-Challwa, 135); pero también la población originaria del Cuzco antes de la conquista incaica parece proceder de la región alrededor del lago Titicaca. Zuidema (192 ss.) la identifica con el Oro-ayllu o el Uru-ayllu, estableciendo una relación con la tribu de los uros quienes aún hoy siguen viviendo en islas flotantes artificiales en la bahía de Puno. Los uros, que forman parte de Cayao, aparecen así como los antepasados comunes de todos los habitantes del reino incaico y poseen por eso también características de Collana; es decir, pueden ser subsumidos-como la sirena del mito del Pez de Oro- a aquel cuarto grupo sin nombre, cuya existencia es postulada por Zuidema (191). El vínculo del Khori-Puma con Cayao, en cambio, se ve confirmado por Churata mismo, cuando escribe: "el Khori-Puma, el Puma de Oro, [es el] símbolo del hombre matriarcal, de la edad lunar” (Churata Antología 14).

${ }^{27}$ Moksa es otro nombre de la Khesti-imilla y significa "almíbar". Lo que importa aquí es la connotación de dulzura, pues la sirena es descrita también a través del sustantivo "miel”.

${ }^{28}$ En los párrafos CXXX y CXXXI del subcapítulo "Paralipómeno Orkopata” (116-20), Churata discute el canibalismo, fenómeno que él considera natural. Visto así, el Khori-Puma, símbolo del hombre prehistórico, sólo obedece a las leyes de la naturaleza, pues el consumo de carne de hombres (cruda o cocida) le otorga al caníbal -así lo afirma el autor-más vitalidad y mejora su salud. Churata postula que también hay que comerse al Pez de Oro -como lo hizo el puma-, para que pueda empezar una nueva era: "EL PEZ DE ORO es eterno, porque es el vértice del Pez; y es necesario que en todos los hombres chispeen sus átomos de oro, para que el hombre se sepa iluminado. Sea milenio antropofágico el suyo, no cuenta. Para crecer, hay que comerlo” (118). La resemantización positiva del antropófago que se apropia de la fuerza y de las virtudes de su víctima (“Obedece a estímulos estéticos y prefiere a los gringos de carne blanda, de azules y cándidos ojos, porque 'siente’ que son bellos y comiéndoselos esa belleza pasará a ser suya de alguna manera. Ciertamente el jefe de la tribu en cuyas manos ha caído una dulce y frágil girl, no la tira, como haríamos nosotros: se la come”, 119) 
debido al hecho de que el puma se ha comido a la sirena y a su hijo común, representará en adelante las tres instancias, cuestionando así por primera vez la oposición entre hanan y hurin. Muy dolido por el crimen que cometió el Khori-Puma se deja llevar por las aguas -¡siendo él un animal terrestre!- y quiere ahogarse en las aguas del Lago de Arriba ("Khori-Puma acabó en miserable pescador que brama pidiendo al Lago de Arriba le devore”). Las observaciones con respecto a las relaciones topográficas del contenu inversé pueden ser resumidas entonces de la manera siguiente:

Ia) Disyunción entre tierra (Khori-Puma) y agua (Tata Titikaka), siendo el resultado del alejamiento en un eje horizontal del agua hacia la tierra por parte de los antepasados del Khori-Puma (véase nota 20)

Ib) No hay oposición entre hanan y hurin, puesto que tierra y agua $\in$ hurin

IIa) Disyunción entre tierra (Khori-Puma $\in$ Cayao) y cielo (Khellwa $\in$ Collana); es decir entre hurin y hanan $\rightarrow$ la Khellwa no es apta como esposa del Khori-Puma

IIb) Disyunción entre tierra (Khori-Puma $\in$ Cayao) y agua $\cap$ cielo (Kheñula $\in$ Payan = Cayao $\cap$ Collana); es decir entre hurin y hanan $\cap$ hurin $\rightarrow$ la Kheñula tampoco es apta como esposa

IIc) Conjunción entre tierra (Khori-Puma $\in$ Cayao) y agua $\cup$ cielo (Khesti-imilla $\in$ Cayao $\cup$ Collana); es decir entre hurin y hurin $\cup$ hanan $\rightarrow$ la Khesti-imilla es la esposa ideal

IIIa) Por la incorporación de la Khesti-imilla y del Khori-Challwa se efectúa la unión de tierra (Khori-Puma) $\cup$ agua $\cup$ cielo $\}$ (Khesti-imilla, Khori-Challwa)

En vista de que ya he aludido a la correlación entre lo cru y el Khori-Puma, también se pueden atribuir ahora las demás categorías lévi-straussianas pourri (podrido), frais (fresco) y cuit (cocido): El representante de pourri = eau mortelle (agua mortal) es el Tata Titikaka, que se ha vuelto ciego a causa de la pérdida de su querida hija; además, también los antepasados muertos (chullpas) relacionados con él -a ellos les corresponden, en analogía con la Khesti-imilla, también características de Collana- sustentan tal interpretación. La representante de frais = eau vitale había sido hasta su muerte (aunque aparezca de nuevo en el transcurso del mito) la Khesti-imilla en su fértil océano estelar; en cambio, lo cuit todavía no parece haberse establecido como principio supremo: el Sol o Tata-Lupi, feu vital (fuego vital), está ausente (la escena parece haber tenido lugar sobre todo en la noche), así que es representado o sustituido por la luna ${ }^{29}$ (que no se menciona,

hace recordar otra vez más el Manifesto Antropófago de Oswald de Andrade. Aunque no hubo intercambio de ejemplares entre el Boletín Titikaka y la Revista de Antropofagia, se puede suponer que Churata conoció (probablemente a través de Mário de Andrade, que publicó dos poemas en el Boletín en mayo 1929, es decir exactamente un año antes de la proclamación del manifiesto, y en cuya casa se encontraron algunos números de la revista puneña) los textos de Oswald de Andrade rápidamente. La "dulce y frágil girl" de Churata tanto como su "milenio antropofágico" parecen aludir (de esta manera, también es posible datar ciertos pasajes de El pez de oro) en todo caso al manifiesto brasileño, donde se lee: "Queremos a Revolução Caraíba. Maior que a Revolução Francesa. A unificação de todas as revoltas eficazes na direção do homem. [...] A idade de ouro anunciada pela América. A idade de ouro. E todas as girls” (14).

${ }^{29}$ En la cosmovisión indígena, la luna está asociada con lo femenino, y su color -plata-se opone al oro del sol masculino. A pesar de que las estrellas, a su vez, normalmente sean consideradas 
pero que tiene que estar presente necesariamente), cuyo resplandor está relacionado metonímicamente con las escamas de plata de la sirena. La situación se presenta entonces así: ${ }^{30}$

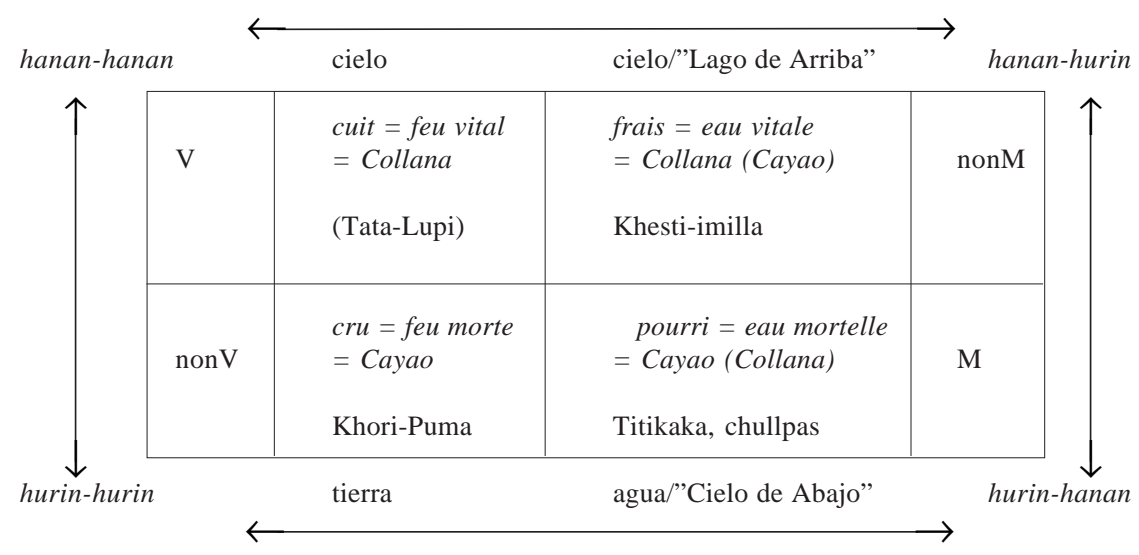

En la secuencia IV (párrafos 14-20) se establece ahora la base para que la situación resultante de los primeros tres episodios se pueda invertir. La voz de Suchi, del Pez de Oro que ha nacido muerto, sugiere al puma desesperado que baje de nuevo del Lago de Arriba al lago Titicaca -otra vez, se observa aquí una disyunción-y que pida perdón llorando ante la tumba de aquél en el Cielo de Abajo ("Tienes que ir al Cielo de Abajo, y llorar a mi vieja Chullpa hasta que cielo con ola se vierta de tu lágrima”, 130). Recién ahora, el Khori-Puma es capaz de hacerlo: porque se ha comido a la Khesti-imilla y a su hijo, el Pez de Oro, -es decir, porque la tierra, el agua y el cielo como feu mortel y eau vitale se han unido en él- se convierte, a través de la substitución del fuego por el agua, en eau mortelle (véase de nuevo el pasaje: "Khori-Puma acabó en miserable pescador que brama pidiendo al Lago de Arriba le devore”), antes de que, finalmente, también el adjetivo mortelle se vea reemplazado por el adjetivo vitale. Como representante temporario de eau vitale el Khori-

masculinas, la Khesti-imilla estelar con sus escamas de plata parece mucho más cercana de la luna femenina. Véase al respecto Urton: "Stars are primarily classified as masculine. [...] However, a note of caution must be entered here. It seems to be a common feature of Quechua classification that objects or categories do not have absolute symbolic values. That is, one must always consider the context within which classifications are made. Thus, although star-to-star constellations as a category are considered masculine, a specific constellation, or one star of a constellation, may be masculine, feminine, or androgynous" (107 y 109). La miel color de oro, que también se menciona al hablar de ella, se puede leer entonces como metonimia de Tata-Lupi, es decir del sol, por lo que se confirma la suposición de que la Khesti-imilla unifica en sí tanto el hanan como el hurin.

${ }^{30}$ Las abreviaciones $V$, nonV, $M$ y non $M$, tomadas de Greimas, significan vie, non-vie, mort, nonmort (vida, no-vida, muerte, no-muerte). 
Puma ahora puede verter lágrimas para que se formen de ellas un charco y después un lago, en el que el hijo nacido muerto, el Khori-Challwa, es reanimado: “¡Cuitado, Khori-Puma (conminábale el Príncipe Suchi): si dejas de llover, y no formas mi laguna; entonces sí me ahogaré!” (131).

El Khori-Challwa -un pez con las escamas de oro y los bigotes de totora heredados de su padre e hijo, además, de un matrimonio entre Collana y Cayao y por eso parte de Payan- ve la luz del mundo por segunda vez en la secuencia V (párrafos 21-30), justo en el momento cuando -así como le ha sido profetizado al Khori-Puma- un puñado de "Lodo Ardiente” cae desde el Lago de Arriba al Cielo de Abajo: "Vers. 23 De pronto, ¡llora que te lloro oro!, del Lago de Arriba cayó la Niña Ardiente [= Lodo Ardiente del párrafo 14; MTB]; y era sólo estrella que se puso a frutecer el Cielo de Abajo, si al punto con el zurrón del Alba apareció la trompetilla bigotuda” (132). La función de este lodo ardiente como elemento que representa el feu vital combinando características tanto del cielo como de la tierra, por lo que establece también un lazo con Payan, destaca por dos razones. Primero, es a través de él que hurin, es decir Pachamama y Khochamama (véanse párrafos 25 y 26), es fertilizado desde hanan, a causa de lo cual el ciego Tata Titikaka recupera su vista y también se inicia el renacimiento del Pez de Oro. Segundo, parece que acontece por medio de esta especie de lluvia ardiente o estelar que evoca la erupción de un volcán -con el diluvio y el terremoto, uno de los tópicos más conocidos del fin del mundo- un pachakuti, que invierte el viejo orden, generando el contenu posé y marcando el inicio de una nueva era. ${ }^{31}$ Dotado de la fuerza viril de Tata-Lupi, el lodo ardiente, sin embargo, tiene una connotación femenina (“Niña Ardiente”), por lo que se lo puede acercar a la “Aurora”, la que todavía no se menciona en el párrafo 23, pero que ya está presente implícitamente, cuando se habla del "zurrón del Alba”, símbolo nietzscheano del comienzo de aquella nueva era. La Aurora juega en la larga escena final VI (párrafos 31-46) un papel preponderante, pero también ambiguo: después de que Tata-Lupi como el representante de la cultura incaica se ha despertado finalmente, emitiendo sus rayos al lago Titicaca donde está nadando el Pez de Oro, dirige la Aurora la palabra al Khori-Challwa para convencerlo de que salga del lago Titicaca -de la lágrima del puma- y se junte con ella:

Vers. 39 Coqueteando sus malignos dientecillos de ámbar entre los oleajes, la hermosa del Lago de Arriba, hizo chispear adamantines estiletes. “ ¡Nadie, sino yo, digna es de tus bigotes de oro, hermoso Príncipe (le dijo). Abandona la thantosa lágrima del Puma, y vuelta locura de tu beso, te seguiré hasta las Chinkhanas del Hollín”. “iQue hermosa eres (repuso el Suchi), sí, Aurora hermosa; pero sólo esta lágrima del Puma es la hermosura[!]” (134 ss.)

\footnotetext{
${ }^{31}$ Más tarde, en el párrafo 48, se habla explícitamente de una "explosión de volcanes” (135), y también el capítulo "Morir de América”, donde se retoma el mito, indica que de hecho se trata de una erupción de volcanes la que inicia la nueva era: "Ver, cuando esperaban no verle más, dirigirse al Palacio de Oro, algo fue que embebía de felicidad ojos, corazones, escamas./ Allí las aguas echaron llamaradas, incendióse el vientre de cristal y hervimos todos en fuego. Tres volcanes habían roto su clausura; [...] Entre el cremor lumíneo, que todo lo abrasaba, se perfilaron las moles eternas de la Khori-wasi./ Trinó EL PEZ DE ORO, querida niña; trinó con sus viejos primores./ ¡Piupiu-titit!/ - He aquí -me dijo-; des hoy [sic] el Palacio de Oro será la chuklla que perdimos. Yo saludo en ti a su Emperador, el Khori-Puma./ ¡Piupiu-titit!” (442 ss., énfasis mío).
} 
Indeciso de entregarse a la Aurora o no -esta última es descrita como un ser carnívoro y maligno al mencionar sus "malignos dientecillos de ámbar”-, el Pez de Oro pide el consejo del Tata Titikaka. Éste le contesta: "Sólo en el corazón, Khori-Challwa, te sentirá la Vida” (135), lo que insinúa que el Pez de Oro no sucumbirá a la tentación de la Aurora, permaneciendo en las aguas del Titicaca. Entre tanto, el Khori-Puma ha sido devorado por las olas, aunque no queda claro si se ahogó en el Cielo de Abajo o en el Lago de Arriba ("en el Lago de Arriba guiñaba la Khesti-Puma; mas ya el Thantoso [sc. el Khori-Puma], por thantoso, era del acial arrastrado al amor de las olas y por piedades de la ola”): la frontera entre arriba y abajo -entre hanan y hurin-resulta borrada ("Rompióse en champis el Cielo de Abajo; argentos disparaban desde el Lago de Arriba”, 134), provocando el hecho de que el Pez de Oro ahora sabe volar ("Con su vuelo redondo EL PEZ DE ORO zambullóse en los ojos de su Lago”) y de que podría juntarse con la Aurora, si quisiera; además, trina como un pájaro (“Allí rompió la ampolleta del trino:/ — ¡Inká piupiu! ¡Titt inká!... [...] Piupiu-titit”, 132). La segunda parte del mito del Pez de Oro -el contenu poséremite pues a las características siguientes:

IVa) Disyunción/oposición entre hanan (Lago de Arriba) y hurin (el chullpa en el Cielo de Abajo); $\rightarrow$ movimiento vertical de parte del Khori-Puma desde arriba hacia abajo para llorar en la tumba de su hijo

IVb) Conjunción entre tierra (Khori-Puma) y agua (lágrima); el Khori-Puma se caracteriza en adelante por tierra $\cup$ agua, superando temporalmente la disyunción de sus antepasados) Va) Conjunción entre $\{$ cielo $\cap$ tierra $\}$ (Niña Ardiente $=$ lodo ardiente) y $\{$ tierra $\cup$ agua $\}$ $($ Pachamama $\cup$ Khochamama $)=$ hanan + hurin; Niña Ardiente $\in$ Payan, puesto que cielo $\cap$ tierra $=$ Collana $\cap$ Cayao $=$ Payan

Vb) Renacimiento del Pez de Oro: hanan $\cap$ hurin $=$ Collana $\cap$ Cayao $=$ Payan (KhoriChallwa); el Khori-Challwa como pez que sabe volar y trinar como un pájaro, unifica en sí las características del agua (hurin) y del cielo (hanan) $\rightarrow$ conjunción entre hanan y hurin

VIa) Conjunción entre tierra (Khori-Puma) y agua (Cielo de Abajo/Lago de Arriba); resultado del movimiento vertical (o horizontal) del Khori-Puma de la tierra al agua (superación permanente de la disyunción de sus antepasados)

Traducido a las categorías de cuit, cru, frais y pourri, esto significa:

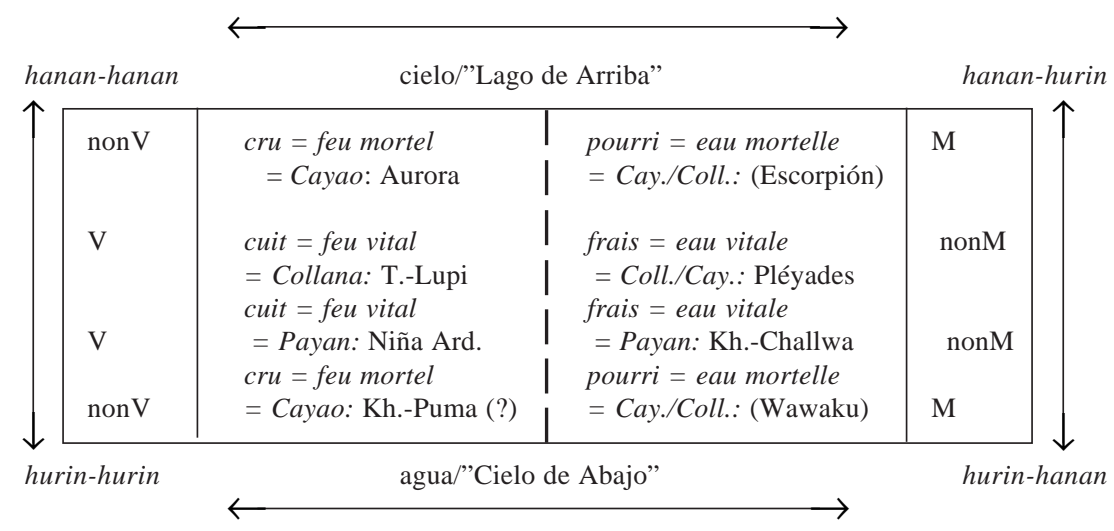


Por cierto, esta ilustración requiere algunas explicaciones. Primero, destaca que la situación que resulta al final de la narración churatiana del mito del Pez de Oro no se ha invertido simplemente, según uno habría podido esperar por las sugerencias que implica la idea de un proceso de transformación de un contenu inversé en un contenu posé. Más bien, parece que los contrarios coexisten desde ahora dentro de los cuatro cuadrantes, puesto que la frontera entre arriba y abajo se ha vuelto penetrable: Tata-Lupi, el representante despierto de lo cuit se ve confrontado, dentro de hanan, con la Aurora carnívora que posiblemente alude a lo cru y que trata de tentar al Khori-Challwa; de la misma manera, lo cuit, la Niña Ardiente, tendrá que resistir frente a lo cru, representado por el Khori-Puma, dentro de hurin, así que se constituye una relación recíproca que se manifiesta en la pareja paradójica del Lago de Arriba y el Cielo de Abajo, siendo esta una expresión del tinkuy. ${ }^{32}$ La misma relación se observa también en las categorías frais y pourri las que se ven representadas ambas tanto en hanan como en hurin: mientras que en hurin pueden ser equiparadas con el Khori-Challwa (frais) y con los chullpas o con el Wawaku ${ }^{33}$ demoníaco (pourri), son simbolizadas en hanan en forma de dos constelaciones estelares distintas.

Greimas (63 ss.) cree discernir en su análisis del mito de referencia Bororo -apoyándose en la interpretación del mito Arekuna por Lévi-Strauss (250)- que las vísceras del padre caído al lago y devorado por las pirañas, cuyos huesos permanecen -parecido a los chullpa-tullus- en el fondo del lago, son proyectadas al cielo en forma de las Pléyades, así que les correspondería la función $M$. Ya que las Pléyades indican el inicio cercano de la estación de las lluvias, siendo los Bororo cazadores y recolectores que saben

\footnotetext{
${ }^{32}$ Evidentemente existe una relación similar en la última novela de José María Arguedas titulada El zorro de arriba y el zorro de abajo. Nótese que el alejamiento de parte del autor de las sociedades indígenas rurales y serranas (arriba) y el acercamiento a la sociedad migrante de las regiones costeras urbanizadas e industrializadas del Perú (abajo) se efectúa todavía dentro de la dicotomía entre hanan y hurin (Lienhard). Hablando de Arguedas, quisiera anotar que Churata anticipa gran parte de su discurso neoindigenista; incluso se puede considerar a Churata -y no a Arguedas, como dijo Ángel Rama- como fundador de la técnica narrativa transcultural par excellence que consiste en trasladar la sintaxis de las lenguas indígenas al castellano en las letras modernas peruanas. Sin poder entrar aquí en el debate alrededor de los emisores y receptores de la literatura llamada indigenista, hay que subrayar, sin embargo, una diferencia importante: Churata no se contenta con estructuras sintácticas quechuas y aymaras que incorpora al castellano, sino que también intenta hacer lo mismo al nivel lexical. Por eso, resulta casi imposible comprender El pez de oro sin hacer uso del glosario al final del libro, y esto imposibilita o, por lo menos, complica bastante el proceso de transculturación que aspira a un grado más alto de coherencia narrativa, revalorizando más bien el factor de la resistencia cultural que, sin embargo, le es inherente. Con respecto a la noción del tinkuy, véase Platt Los guerreros.

${ }^{33}$ A pesar de que el Wawaku, definido por Churata como "[m]itografía de la pestilencia de los pantanos” (El pez 550), no aparece en el mito del Pez de Oro mismo, sino que entra en escena recién en "Morir de América” (492ss.), es descrito de todas maneras como la reencarnación de la muerte y de todo el mal ("el morrillo del WAWAKU [...] es la parte hedionda de la luz, camino de muerte, invitación al miedo”, 533) -es decir, como representante de $M$ que amenaza el democrático Estado nuevo fundado por el Khori-Puma y el Khori-Challwa.
} 
cazar mejor durante la temporada seca, la correlación de las Pléyades con $M$ tiene sentido; ${ }^{34}$ en cambio, para las sociedades agrarias peruanas de los quechua y aymara, el comienzo de la estación de lluvias tiene una connotación positiva. La aparición de las Pléyades en el horizonte se asocia ahí con el retorno del fértil principio femenino de la ukhupacha y con su reunificación con el principio masculino, coincidiendo con la festividad de la siembra (Randall; Urton). Entonces, las Pléyades no representan $M$-habría que buscar $M$ o lo pourri en una proyección de los chullpas en hanan en forma de una constelación estelar que es visible durante la estación seca, por ejemplo en el Escorpión-, ${ }^{35}$ sino nonM, relacionándose con la Khesti-imilla que es la representante de nonM en la ilustración superior. ${ }^{36}$ De hecho, la identificación de la Khesti-imilla con las Pléyades no parece desacertada: en varios mitos de la colección de Lévi-Strauss (por ejemplo $\mathrm{M}_{131 \mathrm{a}}$ Matako o $\mathrm{M}_{134}$ Akawai), las Pléyades son vinculadas con peces y/o con miel abundantes; la Khestiimilla, una sirena con los atributos moksa (“almíbar”) y miel, unifica ambos elementos en sí. Su muerte temporal en la secuencia III, cuando es devorada por el Khori-Puma, se podría interpretar así -en analogía con la desaparición de las Pléyades bajo el horizontecomo su ingreso al mundo de los muertos, a la ukhupacha, donde tiene que regenerarse, mientras que en el mundo superior domina el principio masculino, es decir el Khori-Puma.

Volviendo atrás a hurin (en hanan vale lo mismo), los representantes de las instancias $V$ y non $M$, que generan la cultura -es decir, la Niña Ardiente que da vida y el inmortal Khori-Challwa-, se ven siempre confrontados con $M$ y nonV simultáneamente, contradiciendo la suposición de Greimas, que parte de un destierro de $M$ y nonV al cielo o al agua. Parece, sin embargo, que esta confrontación no amenaza tanto -como lo teme Greimas- lo cultural, sino que genera más bien un equilibrio interno entre las instancias. Por eso, ya no es necesario seguir considerando $V$ y $M /$ non $M$ y non $V$ como oponentes irreconciliables que se excluyen mutuamente $\cdot{ }^{37}$ Es más acertado interpretar el mito del Pez

\footnotetext{
34 “'A l'heure actuelle, chez les Bororo, le lever des Pléiades avant l'aurore survient au milieu de la saison sèche, vers la fin du mois de juin ou au début du mois de juillet. Les indigènes célèbrent alors une fête [...] afin, disent-ils, de ralentir leur course et de prolonger ainsi la saison sèche, favorables aux activités nomades. On voit donc que, comme les Sherenté, les Bororo associent les Pléiades à la saison sèche $[. .$.$] mais qu'à différence des Sherenté, ils prêtent aux Pléiades une connotation$ négative" (Lévi-Strauss, 251).

${ }^{35}$ Urton (113 ss.) menciona dos constelaciones estelares distintas que son designadas ambas con el nombre Collca por los quechuas, a pesar de que estén continuamente en oposición, ya que una constelación siempre se vuelve visible cuando la otra ha desaparecido bajo el horizonte. Mientras que Urton identifica la primera con las Pléyades, relaciona la otra con la cola del Escorpión. Así, el Escorpión parece ser la constelación buscada que representa $M$.

${ }^{36} \mathrm{Al}$ definir la muerte como estado que carece de cualquier movimiento, Churata se pregunta qué pasaría si el curso de las Pléyades se detuviera: “¿Imagina usted lo que significaría que de pronto se detuvieran las Pléyades en medio de la lujuria universal? Si es usted capaz de imaginarlo, diga que ha imaginado la muerte" (El pez 112). Pero puesto que las Pléyades no se detienen nunca, sino que siempre vuelven del mundo inferior, ubicado bajo el horizonte, queda claro que pueden ser consideradas como representantes de nonM.

${ }^{37}$ Es por eso que en el curso del análisis del mito del Pez de Oro he renunciado al modelo de los actantes de Greimas que opera con los términos opposants y adjuvants ("oponentes” y “ayudantes"). Al contrario del mito Bororo, el mito del Khori-Challwa no establece ninguna oposición entre el padre y el hijo, así que tampoco la hay entre $V / M$ y nonM/nonV.
} 
de Oro como proceso de tránsito de un estado prehistórico y matriarcal simbolizado por el Khori-Puma (véase la parte inferior de la nota 26) hacia la alta cultura incaica que se manifiesta en el Pez de Oro, ${ }^{38}$ la que se destaca por una política de equilibrio, garantizando la unión harmónica de los contrarios: el tinkuy. En este proceso, a la clase de Payan (a la que también pertenece el Khori-Challwa) le corresponde una particular función intermediaria: relacionado por una parte, a través de vínculos familiares, a la casta dominante incaica en hanan, Payan es ubicado, sin embargo, en hurin, es decir en medio de la zona habitada por la población común Cayao, posibilitando así la aculturación de esta. La manera según la cual se produce esta aculturación de la población no-incaica difiere, sin embargo, fundamentalmente de las estrategias de asimilación y conversión del régimen colonial español -por lo menos, esto nos quiere sugerir otro mito, el del justo dominio incaico-, en la medida en que a los conquistados les estaba permitido mantener su propia cultura y religión, a condición de que veneraran, además, las deidades incaicas. Esta idea pragmática de dominio implica, a su vez, el tinkuy; es decir, también en las estructuras indígenas del poder, la unión de los contrarios es un factor fundamental.

\section{CONCLUSIONES}

Habiendo matizado en los párrafos anteriores -como lo hace también Huamán- la importancia de la función del tinkuy, no es ninguna sorpresa que éste determinara incluso el urbanismo del Cuzco, la vieja capital incaica. Después de haber demostrado que el dios Viracocha está vinculado con hurin, el sol, con hanan, en cambio, se asombra Zuidema (376)-este asombro es un buen ejemplo de que no se deberían esencializar las conclusiones de un análisis estructuralista- de que la posición de los templos de las dos deidades en el Cuzco contradiga en apariencia dicha relación, dado que el Templo del Sol se encontraba en Hurin-Cuzco, y el templo de Viracocha en Hanan-Cuzco. Zuidema da este esbozo:

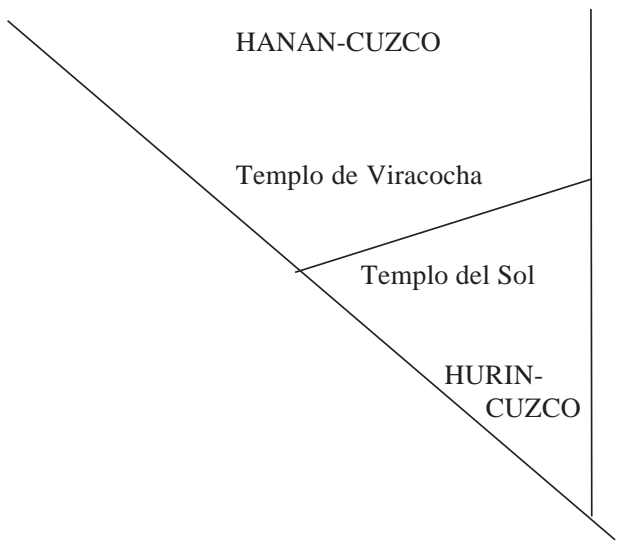

38 "El pez de oro es la imagen del genes del hombre, del hombre de nuestra tierra, esto es el KhoriChallwa, es la semilla del hombre del Tawantinsuyu, nuestra patria histórica” (Churata Antología 14). 
Me parece acertado indicar aquí que este esbozo se parece mucho al símbolo Tai Chi chino ?. el que representa, por vía gráfica, los solsticios y equinoccios que determinan también -como es sabido- el calendario agrario andino (véase Hocquenghem). Hanan y hurin parecen idénticos en muchos aspectos al yin y el yang del pensamiento chino ${ }^{39}$ alcanzando así un potencial de categorías filosóficas, las que -junto con la función del tinkuy, tal como ha sido elaborada en el análisis del mito del Pez de Oro- son de suma importancia para que Churata pueda construir su monismo indígena, alterando la dualidad andina de hanan y hurin, arriba y abajo, hombre y mujer, etc. El tinkuy como la unión de hanan y hurin posibilita la afirmación de la unidad del cuerpo y del espíritu en una base autóctona, convirtiéndose por ende en un concepto sobre el cual se podría desarrollar una filosofía andina. ${ }^{40}$ Más aún: parece que Churata basa su estética vanguardista en estas mismas premisas cosmológicas de las culturas andinas. Aunque en el marco restringido de este artículo no puedo entrar en este debate detalladamente, es de suponer que, en analogía con esa unidad paradójica de hanan y hurin, y de cuerpo y espíritu, también exista un lazo parecido al tinkuy con respecto a la pareja significante/significado, la que concierne a la dimensión meramente literaria de El pez de oro, pues estaría en contradicción abierta con la caracterización corriente de las vanguardias como un espacio del predominio de los significantes sobre los significados. La transformación que efectúa Churata de las poéticas vanguardistas occidentales genera evidentemente un contradiscurso vitalista que sí está en oposición con el logocentrismo occidental, pero sin querer extirpar la racionalidad per se, puesto que ésta también es reclamada para las culturas indígenas. Churata no intenta entonces eliminar el sentido de su escritura -así que gran parte de la terminología que emplean los estudios occidentales sobre las vanguardias le es inadecuada-; tampoco trata de cortar el lazo entre los significantes y sus significados, sino, en cambio, de recodificarlos según un código indígena o, por lo menos, indigenizado. Por eso, se podría decir que el alto grado de hermetismo de El pez de oro se debe al hecho de que está codificado doblemente -desde la perspectiva de la estética de la recepción, se trataría entonces de un texto doblemente provocador-, operando no solamente con un código vanguardista formal, sino que remite al mismo tiempo a un código cultural que se basa en la cosmovisión indígena.

\footnotetext{
39 “Sería útil comparar las nociones de hanan y hurin con las del ying y del yang en el pensamiento chino [...] Esto permitiría reconstituir todas las facetas, la profundidad y la utilidad de estas nociones" (Hocquenghem Hanan 18).

${ }^{40}$ Mario Mejía Huamán intenta en su publicación bilingüe (quechua-castellano) fundar una filosofía andina. A pesar del título interesante de su libro (Teqse. La cosmovisión andina y las categorías quechuas como fundamentos para una filosofía peruana y de América andina), el autor, en primer lugar, le quiere demostrar al público la aptitud del quechua como lengua filosófica, dándole definiciones de nociones filosóficas. Sólo en medida muy reducida, desarrolla un discurso filosófico más profundo; sin embargo, incluso ahí son detectables elementos monistas, cuando escribe por ejemplo: "En la cosmovisión andina la naturaleza es toda la realidad; allí se da todo lo que existe, lo material y lo espiritual. A ella pertenecen los hombres, por ello nadie puede apropiarse de ella. Por otro lado, nada es malo por esencia; el uso es el que hace buenas o malas las cosas; por ello, [...] en quechua no existe el término 'malo', sino lo ‘no bueno' (mana allin)” (67). Subraya además que el quechua originalmente carecía de un concepto propio para el cuerpo, que toma prestado del castellano (115).
} 
Al haber constatado arriba las paralelas entre la cosmovisión andina y china, saltan a la vista las tácticas muy parecidas por parte de poetas vanguardistas en China y el Japón al apropiarse de la poética surrealista y reubicarla en el contexto de la cultura propia: sustituyeron la terminología dialéctica hegeliana que empleaba Breton ${ }^{41}$ por la del yin y del yang. ${ }^{42}$ De esta manera, salen muy pronto del marco teleológico occidental, puesto que la dualidad del yin y del yang -como aquélla muy parecida de hanan y hurin-, a pesar de ser dualidad, no es dualista, sino monista. Visto así, Churata nos proporciona una estética monista ateleológica, una poética que está en armonía con el mundo de arriba y el mundo de abajo, con el mundo de los vivos y el de los muertos. En este sentido, conecta sólo parcialmente con el monismo estético de un José Vasconcelos o con el neoindianismo andino de Uriel J. García, porque ambos conciben sus modelos basándose en una matriz teleológica. Por eso, también hay que tener cuidado con la interpretación del símbolo del Pez de Oro: parece que éste ya no es un simple sinónimo del mestizo tipo síntesis inscrito a un sistema teleológico -aunque a Churata le cueste abandonar esta utopía-, sino que con Churata se inicia el traslado al paradigma posmoderno de la hibridez en las letras peruanas. Se puede observar esta heterogeneidad inherente a la hibridez tanto en el hecho de que los contrarios -como lo ha demostrado el análisis del mito- coexisten, desde ahora en adelante, en un mismo espacio como en un pasaje muy significativo al final de El pez de oro donde se lee: "Cualquier mestizaje es imposible, mas hay alguno impasable; [...] es el del hispano y las lenguas aborígenes de América” (533).

Por todo lo expuesto, se puede decir que con Churata, la vanguardia peruana se ha emancipado de las poéticas vanguardistas europeas, porque toma como base de su discurso la mitología y filosofía de los quechuas y aymaras. Aunque la apariencia de El pez de oro hace recordar todavía textos vanguardistas del viejo continente, su programática ya no coincide con la de ellos ni con las teorizaciones de parte de la crítica literaria al respecto. ${ }^{43}$ Lo que logra Churata, de esta manera, es la relativización-o desvalidación- de

41 “Je crois à la résolution future de ces deux états, en apparence si contradictoires, que sont le rêve et la réalité, en une sorte de réalité absolue, de surréalité, si l’on peut ainsi dire. C’est à sa conquête que je vais, certain de n'y pas parvenir mais trop insoucieux de ma mort pour ne pas supputer un peu les joies d'une telle possession” (Breton 319).

${ }^{42}$ En el pensamiento chino, las artes -y especialmente la literatura y la música- proceden de una interacción entre el yin y el yang, como se lee en Liu: "Literature [wen-chang] is that by which we manifest the signs above and below [i.e., in heaven and on earth], clarify the order of human relationship, exhaust principles, and fully understand human nature, in order to investigate the suitabilities of all things.[...] The forces of yin and yang rub against each other; heaven and earth stir each other. When [this interaction] is roused by thunder, stimulated by wind and rain, moved by the four seasons, and warmed by the sun and the moon, then all kinds of change arise. That is why music is the harmony of heaven and earth" (20). Esta afinidad de las antiguas literaturas chinas, coreanas y japonesas con las poéticas vanguardistas europeas es una de las explicaciones de la gran atracción que ejercían sobre los vanguardistas europeos. En cambio, posibilita esta misma afinidad el proyecto de iniciar una poesía vanguardista oriental detectable, por ejemplo, en los taiwaneses Shang Ch'in y Lo Fu, el coreano Li Sang y los japoneses Nishiwaki, Takiguchi o Fukuzawa. Véanse McDougall; Chang; Linhartová; Bahk.

${ }^{43}$ Tanto en el paradigma de la "deshumanización del arte” de Ortega y Gasset (353-86), como en teorizaciones más recientes sobre las vanguardias, que operan con el concepto de lo "no-orgánico” 
la famosa polémica de Vallejo en “Contra el secreto profesional”, donde se lamentaba de la "inexistente fisonomía propia de los escritores americanos” (92). Iría yo aun más allá de tal constatación: al ser la escritura de Gamaliel Churata la expresión más radical de una vanguardia estética comprometida con la cuestión indígena y con su cultura, existen muy buenas razones para considerar a Churata y a los integrantes del Grupo Orkopata -junto con los Antropófagos y Verde-Amarelistas brasileños- el punto de partida para una reescritura de la historia y teoría de las vanguardias de toda Latinoamérica.

\section{BiBLIOgRAFÍA}

Andrade, Oswald de. "Do Pau-Brasil à antropofagia e às utopias”. Vol. 6 de Obras Completas. Rio de Janeiro: Civilização Brasileira, 1972.

Aramayo, Omar. El pez de oro, la biblia del indigenismo. Puno: 1979 (mimeo).

Badini, Ricardo. L'indigenismo di Orkopata e El pez de oro. Opera al nero della letteratura peruviana. Siena: Università degli Studi di Siena, 1991-1992.

Bahk, Whangbai. El surrealismo poético en el mundo europeo y el extremo oriente. La propagación del surrealismo europeo al Japón y a Corea: y un comparativo de la poesía vanguardista española y coreana. Nueva York: Peter Lang, 1991.

Blumenberg, Hans. Arbeit am Mythos. Frankfurt am Main: Suhrkamp, 1984

Bosshard, Marco Thomas. Ästhetik der andinen Avantgarde. Gamaliel Churata zwischen Indigenismus und Surrealismus. Berlín: Wissenschaftlicher Verlag Berlin, 2002.

Breton, André. Euvres complètes. Marguerite Bonnet, ed. Vol. 1. París: Gallimard ,1988.

Bürger, Peter. Theorie der Avantgarde. Frankfurt am Main: Suhrkamp, 1974.

Carpentier, Alejo. El reino de este mundo. Barcelona: Seix Barral, 2000.

Chang, Han-liang. "The Surrealist Episode in Contemporary Chinese Poetry in Taiwan, 1956-1965”. Proceedings of the $X^{\text {th }}$ Congress of the International Comparative Literature Association. Anna Balakina, James J. Wilhelm, D. W. Fokkema \& Claudio Guillén, eds. New York \& London: Garland, 1985. 307-15.

Churata, Gamaliel. El pez de oro. Retablos del Laykhakuy. La Paz: La Canata, 1957. Antología y valoración. Lima: Instituto Puneño de Cultura, 1971. "El gamonal” (segunda parte). Amauta 6 (1927):18-20.

Cornejo Polar, Antonio. Escribir en el aire. Ensayo sobre la heterogeneidad sociocultural en las literaturas andinas. Lima: Horizonte, 1994.

Deleuze, Gilles \& Félix Guattari. Mille plateaux. Paris: Ed. de Minuit, 1980.

Derrida, Jacques. Die Schrift und die Differenz. Frankfurt am Main: Suhrkamp, 1994.

Diez de Medina, Fernando. “Gamaliel Churata y El pez de oro”. Churata. Antología. 3929.

Flores Galindo, Alberto. Buscando un inca. Identidad y utopía en los Andes. La Habana: Casa de las Américas, 1986.

García, Uriel J. El nuevo indio. Cuzco: H.G. Rosas Sucesores, 1937.

(Bürger), destaca un eurocentrismo que, visto el vitalismo orgánico y humano de Churata y de los vanguardistas andinos, difícilmente se pueda transferir a expresiones literarias vanguardistas fuera de Europa. 
Golte, Jürgen. La racionalidad de la organización andina. Lima: Instituto de Estudios Peruanos, 1980.

Gonzáles Fernández, Guissela y Juan Carlos Ríos Moreno. El proceso americano. Evolución de una estética en los artículos de Gamaliel Churata. (Inédito). Lima: Universidad Nacional Mayor de San Marcos, 1996.

González Vigil, Ricardo. "Surrealismo y cultura andina: la opción de Gamaliel Churata”. Avatares del surrealismo en el Perú y en América Latina. Avatars du surréalisme au Pérou et en Amérique Latine. Joseph Alonso, Daniel Lefort y José A. Rodríguez Garrido, eds. Lima: Institut Français d’Etudes Andines; Universidad Católica, 1992. 111-29.

Greimas, A. J. "Eléments pour une théorie de l'interprétation du récit mythique". L'analyse structurale du récit. Paris: Seuil, 1981. 34-65.

Hartmann, Nicolai. Grundzüge einer Metaphysik der Erkenntnis. Berlín: de Gruyter, 1925.

Hocquenghem, Anne Marie. Hanan y hurin. Un modelo de organización y clasificación del mundo andino. Suplemento de Amérindia 9 (París: 1984). Iconografía mochica. Lima: Universidad Católica, 1987.

Huamán, Miguel Ángel. Fronteras de la escritura. Discurso y utopía en Churata. Lima: Horizonte, 1994.

Lévi-Strauss, Claude. Mythologies. Le cru et le cuit. Paris: Plon, 1964.

Lienhard, Martin. Cultura popular andina y forma novelesca. Zorros y danzantes en la última novela de Arguedas. Lima: Tarea, 1982.

Linhartová, Vìra. Dada et surréalisme au Japon. París: Publications Orientalistes de France, 1987.

Liu, James J. Y. Chinese Theories of Literature. Chicago \& London: University of Chicago Press, 1975.

López Lenci, Yazmín. El laboratorio de la vanguardia peruana. Lima: Horizonte, 1999. McDougall, Bonnie S. The Introduction of Western Literary Theories into Modern China. Tokyo: Centre for East Asian Cultural Studies, 1971.

Mejía Huamán, Mario. Teqse. La cosmovisión andina y las categorías quechuas como fundamentos para una filosofía peruana y de América andina. Lima: Universidad Ricardo Palma, 1999.

Murra, John V. “El control vertical de un máximo de pisos ecológicos en la economía de las sociedades andinas”. Visita de la provincia de León de Huánuco en 1562. Iñigo Ortiz de Zúñiga, Visitador. John V. Murra, ed. Huanuco: Universidad Nacional Hermilio Valdizán, 1972. 2: 427-76.

Ortega y Gasset, José. Obras completas. Vol. 3. Madrid: Alianza, 1983.

Pantigoso, Manuel. El ultraorbicismo en el pensamiento de Gamaliel Churata. Lima: Universidad Ricardo Palma, 1999.

Platt, Tristán. Espejos y maíz. Temas de la estructura simbólica andina. La Paz: Centro de Investigación del Campesinado, 1976.

Los guerreros de Cristo. La Paz: Plural, 1996.

Plessner, Helmuth. “Ausdruck und menschliche Natur”. Vol. VII Gesammelte Schriften. Frankfurt am Main: Suhrkamp, 1982. 
Rama, Ángel. Transculturación narrativa en América Latina. México: Siglo XXI, 1987. Randall, Robert. "The Mythstory of Kuri Qoyllur: Sex, Seqes, and Sacrifice in Inka Agricultural Festivals”. Journal of Latin American Lore 16, 1 (1990): 3-45.

Santacruz Pachacuti Yamqui, Juan de. "Relación de antigüedades deste reyno del Perú". Crónicas peruanas de interés indígena. Vol. CCIX de Biblioteca de autores españoles. Desde la formación del lenguaje hasta nuestros días. Madrid: Atlas, 1968.

Szeminski, Jan. Un kuraca, un dios y una historia : Relación de antigüedades de este reyno del Pirú por Don Juan de Santa Cruz Pachacuti Yamqui Salca Maygua. Buenos Aires: Universidad de Buenos Aires, 1987.

Unruh, Katherine Vickers. The Avant-Garde in Peru: Literary Aesthetics and Cultural Nationalism. Ann Arbor, 1984. (Mimeo).

Urton, Gary. At the Crossroads of the Earth and the Sky. An Andean Cosmology. Austin: $\mathrm{U}$ of Texas P, 1981.

Vallejo, César. La cultura peruana. Crónicas. Enrique Ballón Aguirre, ed. Lima: Mosca Azul, 1988.

Vasconcelos, José. “Monismo estético”. Obras completas. México: Joaquín Mortiz, 1961. 4: 9-92.

Vich, Cynthia. Indigenismo de vanguardia en el Perú. Un estudio sobre el Boletín Titikaka. Lima: Universidad Católica, 2000.

Wise, David. "Vanguardismo a 3800 metros: el caso del Boletín Titikaka (Puno 19361930)”. Revista de crítica literaria latinoamericana 10, 20 (1984): 89-100.

Zevallos Aguilar, Ulises Juan. Indigenismo y nación. Retos a la representación de la subalternidad aymara y quechua en el Boletín Titikaka (1926-1930). Lima: Instituto Francés de Estudios Andinos; Banco Central de Reserva del Perú, 2000.

Zuidema, Reiner Tom. El sistema de ceques del Cuzco. La organización social de la capital de los incas. Lima: Universidad Católica, 1995. 